A publication of the Muma College of Business | University of South Florida

\begin{tabular}{lll}
\hline Volume 5 & Number 7 & 1 JUNE 2020 \\
\hline
\end{tabular}

YAMEN ELSAID, SARAH HANSON, CHRIS LAWSON, IVAN MONTERO \& COLIN PROVINE

\title{
DRIVING PROFITABILITY AT THE HUNGRY DRAGON1
}

\author{
The bar or tavern space can be quite dynamic and challenging...Could leveraging smart \\ marketing investments result in a thriving and profitable business?
}

The local neighborhood watering hole was an age-old tradition in cities and towns across America. Such "dive" bars were often frequented by regulars (repeat local customers who the bartender may well know by name) as well as transient customers who happened to be in town or noticed the inviting bar signage in passing. When long-time Floridian Piers Ikerd was looking to transition from the corporate world in the summer of 2018, he sought more independence and ideally the opportunity to take over and transform an existing business. After many years in retail environments, most recently as a district manager for Ashley Furniture, he looked locally for an appealing business or franchise opportunity. A neighborhood bar in the Temple Terrace, Florida area, called Aces N Eights, caught his attention.

Perhaps this was the kind of challenge Ikerd was looking to take on. Transforming a struggling bar that was located favorably in the vicinity of both the University of South Florida's sprawling campus and the popular Busch Gardens amusement park offered potential and intrigue. His years in furniture retail convinced him of the importance of attracting and driving customer traffic through the front door. Half the battle was often gaining customer awareness in an increasingly crowded and dispersed marketplace. In many retail establishments, garnering more loyal and frequent patrons resulted in greater revenue and ultimately greater bottom line profits.

Ikerd subsequently pulled in two of his best friends and one of their spouses as investment partners and purchased the bar, rebranding it as The Hungry Dragon Tavern (THDT). These fellow investors shared Ikerds vision of creating a more attractive and welcoming bar, but like him were not exactly sure how to best capture the attention of new customers while simultaneously not only keeping, but increasing, the loyalty of existing patrons. Their work on an initial business plan convinced them that the key to improved profitability would ultimately center on getting more customers in the door who stay a while, had a good time, and would come back again soon.

Could Ikerd and the team transform their new bar into a more popular and profitable establishment? What would be the best approach to take THDT to the next level beyond the changes already made tweaks to the food and beverage menu, remodeling the interior and changing the bar's concept? Leveraging marketing knowledge to assess the local market? Sticking to traditional marketing? Increasing social media presence and brand awareness? Utilizing market technology and tools to creatively capture potential customers? The new owners hoped to make the right marketing-related moves to breathe fire and profit into the Hungry Dragon.

\footnotetext{
${ }^{1}$ Copyright $($ 2020, Yamen Elsaid, Sarah Hanson, Chris Lawson, Ivan Montero, Colin Provine. This case was prepared for the purpose of class discussion, and not to illustrate the effective or ineffective handling of an administrative situation. Names and some information have been disguised. This case is published under a Creative Commons BY-NC license. Permission is granted to copy and distribute this case for non-commercial purposes, in both printed and electronic formats.
} 


\section{Alcoholic Beverage Industry}

\section{Global Adult Beverage Market}

When Ikerd bought THDT, globally, alcohol sales were projected to increase year over year for the foreseeable future. The global alcoholic beverages market accounted for revenues of $\$ 1324.1$ billion in 2017 and was expected to reach $\$ 1864.2$ billion by 2026 (Smith, 2018), growing at an annual rate of nearly $4 \%$ during this period. Alcoholic beverages received their name from ethanol (pure alcohol), a key raw material ingredient. Alcoholic beverages were usually classified into several major categories, including beer, wine and spirits. Flavored variations on these categories and mixed drinks were also frequently bought to quench the world's thirst; popular products included sangria, cider and cocktails. At the end of 2017, there were over 66 billion gallons of alcohol consumed with the beer category leading the way at over 20 million cases distributed globally.

\section{Domestic Adult Beverage Market}

By 2018, the alcoholic beverage industry accounted for almost $2 \%$ of the total U.S. GDP, a small but steadily growing part of the domestic economy (American Beverage Licensees Admin, 2018). Driven in part by a $20 \%$ increase in the number of alcohol retailers over the previous ten years (Exhibit 1 ), the beverage industry continued to represent a notable segment of the economy with regards to sales, industry jobs, and generated tax revenue. By 2016, the U.S. per capita ethanol consumption (age 14 and over) was estimated at 2.35 gallons of ethanol, split into beer (1.08 gallons of ethanol), wine ( 0.44 gallons of ethanol), and spirits (0.83 gallons of ethanol) (Pelletier, 2018; Ritchie, 2019). For perspective, using the ethanol conversion coefficient for beer of 0.045 , the U.S. per capita ethanol consumption was equivalent to 24 gallons of beer in 2016. Of interest, the percentage of alcohol abstainers in America is estimated to be around 40\%. (Jones, 2013.) While alcohol consumption grew 3\% overall from 2006 to 2016 domestically, beer declined with $10 \%$, while wine grew $19 \%$ and spirits grew $17 \%$ (Haughwout \& Slater, 2018).

\section{Consumer Preferences}

As of 2016, the United States market followed the same trends as the world market with beer remaining the volume leader over both wine and spirits overall (Exhibit 2). Large domestic breweries dominated the market, although stiff competition from smaller breweries and imports had drastically shifted the landscape. Small breweries and importers had doubled their market share over the previous 10 years (Exhibit 3). The rate of consumers dining out and partaking in entertainment where alcoholic beverages were available also led to a more robust demand (National Restaurant Association, 2014).

\section{Wine-Based Liquor}

In addition to the traditional alcohol categories, some bars had started serving wine-based liquors as a way to circumvent obtaining a full liquor license (Cowley, 2016). Premium Blend, the main vendor of these wine-based liquors, had been in business since 1989 and offered a wide range of liquor substitutes with 17-24\% alcohol, such as Rhumbero Superior (rum) or Tequesta Gold Agave Especial (tequila). Bartenders could craft elaborate cocktails with these liquors and although the liquor substitutes had a sweet aftertaste, many customers never noticed or minded the difference. Premium Blend aggressively marketed to bars possessing a beer and wine only license (Exhibit 3).

\section{Liquor Licenses}

An establishment such as a bar or tavern was required to secure a (hard) liquor license to sell particular types of alcohol, generally called spirits. State and local governments typically set the requirements for, and controlled the issuance of, these liquor licenses. The licenses tended to be heavily regulated, much 
more expensive than beer/wine licenses and governments stipulated rigorous terms and conditions to maintain the license. A proprietor had to decide specifically what type of establishment they sought to have and what type of alcoholic beverages she hoped to serve. The availability, acquisition cost and maintenance cost of a liquor license varied county by county and had to be carefully considered. Liquor licenses in and around Tampa, where THDT was located, routinely cost well over $\$ 100,000$ to obtain, a considerable cost for small establishments that often took years to earn back. Alternatively, for only $\$ 100$, establishments could enroll in an annual lottery. If selected, a liquor license would cost about $\$ 11,000$. Due to the limited number of available licenses and the profit potential reselling a liquor license obtained so cheaply, it was common for fortune seekers to enroll in the lottery, thereby diluting the candidate pool and further reducing winning chances. Once a liquor license was obtained, the costs for upkeep were low, about $\$ 1,000$ every 1-3 years for renewal. In comparison, a license allowing beer and wine to be consumed on the premises had an annual fee of typically $<\$ 1,000$ per year.

\section{The Business and Initial Changes \\ "Feed the Dragon in You!"}

\section{Neighborhood Bar}

When Ikerd decided to buy THDT, it had been a neighborhood bar in various iterations for decades. The previous owner had only owned the bar, then called Aces N Eights, for just over a year. In addition to creating a "biker" bar with limited appeal, he made costly decisions that eventually proved detrimental to the business bottom line. Some of these mistakes included letting his dog roam freely throughout the establishment and failing to keep the place comfortably cool during sweltering hot Florida days. He was rather unresponsive even when his customers specifically requested more air conditioning, not realizing that the increased cost for a lower temperature was preferable over losing paying customers in the end.

THDT, an independently owned and operated bar, nestled itself on the borders of two iconic locales in north Tampa: the University of South Florida (USF) and the Busch Gardens amusement park. Given its unique atmosphere and laid back vibe, THDT offered local patrons and transient travelers alike a one of a kind experience. From its locally sourced beers to its custom themed nights and hand-tossed pizzas, visitors were sure to have a memorable and relaxing respite from their hectic or stressful day. As one of only twenty-five locally owned and operated bars within a five-mile radius of this vibrant area, the bar endeavored to provide any and all walking through the door a relaxing time.

The purchase included a few different entertainment options as well such as dartboards, a basketball ring, and even an old school jukebox to spit out tunes. In good years these options had yielded additional revenue streams with the benefit of customers spending more time at the bar, but in recent years the generated revenue had fallen below $10 \%$. By this point, only the jukebox was in use multiple days a week.

\section{Customers and revenues}

Most of THDT's customer base came from the surrounding neighborhoods and they were considered valued, local patrons. Although there were not many independently owned bars in the local area, customers did have a variety of options within the vicinity when it came to food and beverage choices overall, including popular full-service chain restaurants such as Olive Garden, as well as smaller restaurants specializing in Asian, Italian, Mediterranean or American cuisine. About twenty percent of the customers walked in from two hotels within a block of THDT. These travelers were typically construction 
workers staying for a week at a time for local gigs, looking for a conveniently located source of cold beer, tasty appetizers, relaxation, and fun. Since THDT did not possess a liquor license, its main sources of revenue were beer, wine, and food. At the time of the acquisition, alcohol made up roughly $75 \%$ of the sales volume. Revenues were usually twice as high in the winter compared with the see e.

\section{Rebranding}

Encouraged by his new ownership of a neighborhood bar with promising potential, Ikerd decided it would be best to implement initial changes to spur more success in the future. As the building was over fifty years old, Ikerd had to invest upfront to renew the plumbing and to paint the walls. However, first and foremost was changing the name of the bar, as Ikerd felt that 'Aces N Eights' did not sufficiently reflect the fact that the bar had an extensive food menu. The new name, 'The Hungry Dragon Tavern' would better convey to potential customers that this was a bar with drinks and an enticing food menu. With the name change came an updated brand and bright, inviting colors on the exterior signage (Exhibit 4). Ikerd hoped this would increase the visibility from the road and attract more walk-ins. Next, he upgraded the furniture with more comfortable couches and convenient standing tables sourced on Craigslist. He built a small stage to accommodate bands and host events himself. Lastly, he improved the ambiance by swapping some of the lightings for candle look-a-likes to complete the more intimate Hungry Dragon look and feel.

\section{Entertainment}

Ikerd evaluated his entertainment devices. He switched out the unprofitable basketball ring for a crane machine. The jukebox turned out to be the most profitable device, making nearly $\$ 300$ in any given month. In addition, patrons would stay longer and spend more if they could make their own music choices. Ikerd soon realized that every decision he made came at a cost, as some patrons would not appreciate the loud music from the jukebox. The Putt-Putt video golf game stayed as it was popular with a couple of loyal customers. After a bit of informal surveying, Ikerd also introduced two slot machines that became instantly popular with the regulars but did not significantly drive any new business.

\section{Menu}

As for the food, Ikerd searched for cost-effective yet popular and flexible ingredients that would improve the appeal of his menu items while keeping costs low. He was able to diversify the menu while keeping the variety of ingredients limited. Threequarters of the menu consisted of pizza and sandwich variations. Other items included tater tots and nachos. Especially the pizza was very well received. THDT had come with a limited size pizza oven, allowing Ikerd and his bartenders to bake two pizzas at a time.

With the food quality at THDT now superior to other establishments in the immediately surrounding area, he aspired to apply for a discounted liquor license once at least $51 \%$ of his revenues became food-driven, as per Florida State Law. In addition, customers who came in for food stayed about $30 \%$ longer than drink-only customers, thereby increasing their amount of drinks purchased. The fresh culinary updates turned THDT into a more comfortable bar, with a broad assortment of food and drinks and enough entertainment to keep the regulars happy and occupied (Exhibit 5). A picture of the menu is shown in exhibit 6.

\section{Events}

Ikerd experimented with different types of events in an attempt to attract new customers. Events were a great opportunity to market more aggressively, and he was actively looking at presenters who could bring their fan base into the bar and partake in karaoke or trivia. He had to balance this against the costs of an event. Karaoke, at \$100 per night, added less than five customers on average over three hours. Musicians 
were appreciated by the regulars, but the more budget-friendly musical options did not typically come with a fan base. Latin Nights using the jukebox were free to organize and garnered more appeal to Hispanic locals, a demographic that had not traditionally frequented THDT, however, their business did not carry over to nights outside of the Latin Nights. The added revenue from karaoke and live music nights did not offset the additional cost.

\section{Early Results}

Although many legacy patrons initially eyed Ikerd with some distrust as the new owner, his personable nature led them to gradually appreciate the transformation of the bar. Patrons who had left the bar under the previous manager were returning within months to give it another shot. During the first eight months Ikerd owned the bar, he saw a steady increase in the number of customers and accompanying sales. After eight months the growth stabilized and THDT was hovering around the break-even point. Revenue came from alcohol (60\%, out of which $80 \%$ came from beer), food (35\%) and games/entertainment (5\%). The slow influx of new patrons had dried up and Ikerd turned to his marketing plan to further advance his business.

\section{Marketing}

\section{The Need for Marketing}

Ikerd had mostly relied on word of mouth during the first few months, in addition to a relatively untargeted approach of Facebook and Google reviews written by regulars. As he became convinced that something else had to change to turn THDT into a profitable business, and as he had already revised branding, drinks assortment and food quality/choice, marketing seemed to be a logical strategy to tackle next.

He made sure to change his marquee out twice a week with rotating offers, focusing largely on pizza and wine-based cocktails. Ikerd had to carefully weigh his options due to his limited budget and due to what the regulars could tolerate with regards to pricing. Tapping into new sources of bar patrons might upset the regulars who felt a sense of belonging and ownership at the bar. The sensitive balance was evident when loud groups from one of the adjacent hotels dropped in causing many of the regulars to leave, an age-old dynamic in the bar world. Marketing spend typically varied between 4-24\% and depended on a number of different factors, such as industry and reach (Moorman \& Finch, 2017).

As a result, Ikerd did not know which marketing channels and topics to focus on or invest in. Paper marketing might appeal more to his older demographic, but social media would be cheaper and came with its ability to target specific zip codes. Ikerd had little experience with digital marketing and it would be time consuming to keep social media appropriately updated. Moreover, he was unsure about how to measure the effects of his actions and how to quantify the impact of his investments.

\section{Traditional Marketing}

Traditional business marketing strategies typically involved print media (e.g., coupons, advertisements, and flyers), broadcast media, direct mail, and telemarketing (Exhibit 7). Ikerd could buy advertising space in local papers or add coupons. The smallest advertisement on the local pages of the Tampa Bay Times would cost him $\$ 504$ and Ikerd expected to have to repeat advertise to drive customers (Times Total Media, 2020). Smaller papers would be as cheap as $\$ 66$ for an advertisement. 
ELSAID, HANSON, LAWSON, MONTERO \& PROVINE

Alternatively, the proximity to Busch Gardens and USF opened up an opportunity for strategic partnerships. Ikerd considered introducing an "industry night" with discounts for Busch Gardens employees. Other options were distributing materials on the USF campus and to the adjacent hotels. A benefit to traditional marketing was that consumers were familiar with the method and understood it intuitively. Working against such traditional methods was the inability to accurately gauge how many people received the message or were directly influenced to patron the bar as a result. Other factors working against traditional marketing were cost and lack of interaction with the customer.

\section{Digital Marketing}

For many businesses, traditional marketing was no longer enough as the world had largely become a digital marketplace. Digital marketing encompassed all marketing efforts that use an electronic device or the internet itself and it offered some advantages that were appealing to Ikerd. Digital tools included websites, content marketing, video marketing, banner ads, and social networking sites such as Facebook and Instagram. According to the 2015 Social Media Marketing Industry Report published by the Social Media Examiner (Delzio, 2015), 96\% of small businesses said they used social media in their (digital) marketing strategy. They used a variety of applications (Abdoulaye, 2014; Exhibit 8).

Most modern platforms used algorithms to deliver digital content to users. Algorithms were a set of rules or calculations used to pinpoint user interests based on consumers' online behavior. Results were delivered to the user in a precise and calculated manner based on interests, recency, or social media connections. Algorithms used on these platforms generally worked with a ranking system whereby the calculation delivered results to the user based on the aforementioned factors. Algorithms were not a new marketing tool; however, in modern digital marketing algorithms tracked customer behavior in real-time as opposed to the days, weeks, or even months it took to assemble data on customer patterns with traditional marketing. With the growing use and dependency on smartphones, digital marketing strategists learned to capitalize on advertising which was delivered directly to the hands of the smartphone user, not unlike distributing a digital flyer to every user. Digital marketing brought with it the capability to specifically target potential consumers based on their online behavior and the ability to track its effectiveness immediately. Costs and the ability to directly interact with the consumer were additional upsides of digital marketing. The downside to digital marketing was the inability to reach non-smartphone users, potentially excluding customers, especially amongst the older clientele that frequented THDT.

\section{Smartphone Use}

While most digital platforms were readily available on desktop computers and laptops, most people would use them on smartphones. Smartphone use was ubiquitous: $90 \%$ of millennials (aged 18-34) and $60 \%$ of baby boomers (aged 55-64) owned or regularly used a smartphone by 2014 and this number increased year over year (Pew Research Center, 2019). According to a 2020 survey from MGH, half $(45 \%)$ of U.S. diners said they've tried a restaurant for the first time because of a social media post made by the establishment itself, while $21 \%$ claimed posts could be a deterrent. Further, $22 \%$ said a restaurant's social post enticed them to return (MGH Report, 2020). (Exhibit 9). Within those groups, 53\% of millennials and $26 \%$ of baby boomers were more likely to use restaurant options now than two years prior (Abdoulaye, 2014). Two-thirds of Americans used smartphones or tablets to search for restaurant options (Pew Research Center, 2019). An online survey conducted by marketing agency MGH showed that $89 \%$ of American diners had a social media account. $45 \%$ of diners tried a restaurant for the first time because of a post made by the establishment, and $21 \%$ decided against trying a restaurant because of social media (MGH, 2020). Despite a potential selection bias by conducting this survey online, the industry had surely changed and consumers were embracing that change. 


\section{Applications}

The new tools had become staples in modern marketing strategies for most businesses and small, independently owned businesses in particular. Geo-location technology allowed digital tools to tailor their recommendations to their customers. Many applications were initially created to take advantage of the connectivity people share with their smartphone devices. However, apps had become repetitive and borrowed data from each other and then presented that data through different visualizations. The continuous rapid change of the digital environment posed a challenge and required continuous attention to the marketing mix. Five brands, in particular, stood out among the thousands of applications (Exhibit 10).

\section{Yelp}

Yelp was one of the most popular online review sites and apps used by smartphone users early on. This application allowed bar/restaurant owners to create and manage a profile online, which essentially became a digital storefront for their business. Like with Facebook and Google, customers based their decision on a star score and reviews left by other customers. Although upon introduction a popular platform for customers to locate their next meal, it had lost considerable market share in recent years and in 2019, ranked well below Facebook and Google reviews. (Datanyze, 2019).

\section{Facebook}

At the time Ikerd bought THDT, Facebook was the most widely used form of social media. This application and social media platform used by millions of users and could help business owners stay in touch and connected with their followers. Facebook also offered analytical tools to help business owners analyze their targeted customer base and made it possible to target specific zip codes when buying advertisements.

\section{Foursquare}

When Foursquare launched in 2009, it was hugely popular and the app was on track to become the next Facebook. The app let users virtually check themselves in at different locations and awarded digital badges for check-ins, thereby building a highly accurate customer and data map. Foursquare was a useful tool to locate restaurants and bars and its clear and brief visualization helped last-minute decision-making customers. When growth leveled off in 2013 Foursquare envisioned to specialize in intelligent, personal recommendations, but failed to stand apart. It then pivoted to become a data mining company and to create consumer maps while being mindful of customer's privacy.

\section{Instagram}

Instagram was a picture-heavy application that unlike the other platforms, did not rely on reviews to attract customers. Instead, customers subscribed to local pages or to influencers which were members with a considerable following who often used their fans to promote specific products and establishments. The platform utilized so-called "hashtags" between 1-5 words without spaces to 'tag' or 'label' a picture, e.g. \#bestfoodintheworld. The hashtag served as a metadata tag to help users quickly find specific content online and on social media platforms. The food and restaurant business lent itself particularly well for mouth-watering pictures on Instagram. The platform was popular with younger demographics in particular. 


\section{Google}

As of 2019, Google remained the most popular search engine in the world and had been so for decades, with over $88 \%$ desktop search engine market share (Clement, 2019). Google Maps was an extension of a "web-based service that provides detailed information about geographical regions and sites around the world." This platform allowed users to take advantage of the combination of geo-location services and the most powerful search engine in the world to find their favorite bars and restaurants.

Google reviews would be among the first results people saw when Googling for a specific establishment. Users did not need to download an app or even an account to use Google; they could access the website with any internet connection, search for a restaurant either by location or name and then instantly see its reviews. These reviews would also be visible to people who had not initially been looking for reviews, even if they just wanted to learn more about a particular area or business. Paid advertisements would populate first in the visualization results.

\section{Online Presence}

All in all, social media marketing was ideal for bars and restaurant owners with limited budgets and a general inability to afford to hire more traditional and more expensive professional marketers. In the social media and digital age, creating and maintaining an active online presence had in most cases become vital to the livelihood of small bars and restaurants. These establishment's online reputation could make or break revenues as diners preferred to frequent establishments with good ratings and reputation. Modern consumers were not shy about leaving candid commentary and frank reviews online. Nearly $90 \%$ of consumers were influenced by online comments and reviews (Chen, 2016). Curating reviews and comments online did not only afford the business owner a chance to clarify misconceptions on the spot but allowed business owners the opportunity to interact with their customer base directly, thereby learning how to best meet their needs.

It would be difficult to choose the right mix for digital marketing as Ikerd did not have the capacity to keep track of every possible platform given his hectic schedule. Based on his initial research and the comparative overview he created for his informally sourced top 5 applications, Ikerd confirmed that Facebook and Google were most applicable to his target demographic. Foursquare no longer focused on restaurant reviews, whereas Instagram was more popular with a younger crowd and Yelp had lost considerable market share to Facebook and Google.

Social media which allowed advertisements also allowed for customizable options such as ad scheduling, geotargeting, and device targeting. The cost of advertising was comparable between applications and highly dependent on the selected options. The marketing mix was highly customizable and Ikerd could start advertising on Facebook or Google for as little as \$20 a week. If he spent more, he could either run his advertisements more frequently or expand his reach to include more zip codes. To run multiple advertisements per week in a limited number of zip codes for a specialized target demographic, Ikerd estimated he would need to spend $\$ 100-\$ 300$ per app per month. A downside was that Ikerds decision on frequency of ads was largely arbitrary. Neither app offered any feedback and when using advertising on a small scale, like Ikerd was doing, it was very difficult to measure effectiveness.

As a rule of thumb, Ikerd's digital marketing budget should be between 5-10\% of his monthly sales. Sales had seen a gradual increase since he bought THDT; however, sales had fallen flat for the last 3 months. Ikerd calculated his expected marketing budget based on his sales of $\$ 8.000$ a month (exhibit 11), however, even with his experience in the retail industry and observing the effectiveness of marketing 
firsthand, it was difficult for him to endorse the recommended spend of \$354-\$814 when he was unable to turn a profit.

Alternatively, he could choose to completely focus on the business and outsource the digital strategy to a specialized marketing company for a couple of hundred dollars per month. A more budget-friendly option would be to enlist a student, who would be able to provide the same services for $\$ 50-\$ 100$ a month. Any management cost would be in addition to the cost of advertising.

\section{Firing up the Dragon: The Challenges Ahead}

\section{Vision}

Ikerd saw the THDT purchase as an opportunity to win back prior customers while at the same time creating appeal and excitement for new customers. He thought he could improve profitability by making better decisions and smarter investments than his predecessor. Ikerds vision for THDT was to create an attractive, friendly establishment where families would stop by during the day for food and entertainment, and where students, regulars, and tourists alike would frequent at night and then tell their friends about their great experience. With focus and discipline, his vision was achievable.

\section{Demographics}

The median household income in the United States was $\$ 58,000$ in 2018. The median household income for zip code 33612, where THDT was located, was significantly lower at $\$ 31,000$ (Census, 2018). Almost a third of the individuals in this area lived below the poverty level. The median age in the same zip code was 35, while most visitors at THDT were in their fifties or sixties. This would pose a potential problem to attracting USF students, as they might be more attracted to a bar with a younger crowd, while the regulars at THDT likewise were not so enthusiastic to welcome students into their favorite bar with open arms. These dynamics risked keeping Ikerds margins rather low. Even a temporary $\$ 0.25$ price increase for a single beer had caused several price-sensitive patrons to frequent slightly cheaper neighboring bars instead. The disadvantage of more expensive alcohol offset a longer travel distance or picking an establishment without food options. While the previous owner had sold some beers below their acquisition cost, Ikerd was not willing to do so financially.

\section{Liquor License or Not?}

THDT possessed a beer and wine license, but no liquor license, contributing to the attractive acquisition cost of the bar. Although most customers were happy with the wine-based liquor cocktails, the absence of a liquor license was in effect a competitive disadvantage and limited the interest of many college students and certain Busch Gardens employees to try out THDT. The most popular bar in the area was the Pit Boss Lounge, which served no food but did have a full liquor license. Because the Pit Boss had a lot more customers than THDT, they could lower their margins in order to undercut THDT on beer pricing. There were three main ways for an establishment such as THDT to obtain a liquor license which would grant the bar the rights to pour liquor on the premises, but not to carry it out (Florida Legislature, 2019).

1. Buy the license outright, either from another business or from the state directly

2. Enter into an annual state lottery. The fee to enter was only $\$ 100$, but chances to win were slim

3. Obtain a license based on food sales. To be eligible, $51 \%$ of the revenues of a business had to come from food and the establishment had to seat a minimum of 150 people. 
Ikerd considered all three options carefully, as obtaining a liquor license would reduce his market competitive disadvantage. THDT did not have a 150 person seating capacity and revenue from food was only $30 \%$ at the time. Ikerd ultimately decided his profits did not allow for a liquor license acquisition.

\section{Labor}

As THDT was a struggling bar when Ikerd took over the business, his options when hiring new personnel were limited. Finding reliable and trustworthy employees was difficult, especially in the retail space. Ikerd had experimented with different approaches, starting by having a different server each day to appeal to different customers, but he quickly learned that the regulars liked to see a familiar face when coming to their favorite watering hole. Because tips were generally low, most applicants only wanted to work 1-2 days a week as a second or third job. Ikerd soon switched to one regular bartender during the evenings, when he saw the most business come through the door, with additional bartenders during the day and on the weekend. Although he received positive feedback from the regulars on the changes, this left him more reliant on his main bartender. It often meant that he had to cover for her when she was not available for her shift for some reason.

\section{Marketing}

In today's competitive environment, word-of-mouth is rarely enough to establish a profitable business. Ikerd knew his initial improvements had elevated the bar and attracted new customers. Ikerd had exhausted his free options: changing out his marquee biweekly with rotating offers and asking his regular customers to write Facebook and Google reviews. Ikerd did not know which marketing channels and topics to focus on or invest in. Paper marketing might appeal more to his older demographic, but social media would be cheaper and came with its ability to target specific zip codes. Ikerd had little experience with digital marketing and it would be time consuming to keep social media appropriately updated. Moreover, he was unsure about how to measure the effects of his actions and how to quantify the impact of his investments.

\section{The Decision}

While Ikerd remained optimistic that he and his team could unleash The Hungry Dragon Tavern, he knew that the business must become more profitable to justify their leap of faith. To make his investment a success, he needed to make smart marketing choices to get more patrons through the door, spending money and having a good experience that they would tell others about. He knew the success of his bar was multifactorial and he would have to continue making decisions about liquor license application, event programming and menu, even though initial changes to the bar had driven only incremental improvements in traffic.

The decision immediately before him, however, was which marketing approach to choose to optimize traffic. Ikerd saw the advantages and accessibility of online marketing but did not want to forego on traditional options. He wanted to choose the right combination approach to make his business thrive. What would be the most efficient and impactful marketing strategy, taking his budget considerations into account? Would it be enough to help the Hungry Dragon take flight?

\section{The options were:}

1. Develop a strong, comprehensive digital marketing strategy that leveraged the latest in social media tools and channels to drive awareness and attract customers. This involved targeted Facebook ads, smartphone apps and an assessment of other diverse, digital tools. 
2. Use tried and true traditional marketing and old fashioned word-of-mouth marketing tactics to gain attention and increase customer traffic. This included posters, flyers, and fostering strategic relationships with Busch Gardens, USF, and local hotels.

3. Hire a third party (individual contractor, friend, bar regular, marketing firm, student) to help develop and implement a robust and comprehensive marketing plan of attack. This should include the latest in marketing best practices and know-how.

4. Do nothing. Maintain the status quo and rely on the legacy customer base while keeping operating costs low by spending a little as possible building the brand and chasing new customers.

Ikerd took a sip of his Rhumbero Superior and Cokebeer as he looked around his bar. He had spent a lot of time to set himself up for success in the past months. Now he had to figure out how to tip the scales and turn his hard work into a profitable business. 


\section{References}

Abdoulaye, L. (2014). 5 Effective Social Media Marketing Sites for Restaurants. National Restaurant Association Report. Retrieved from https://medium.com/inbound-marketing-clinic-at-nyu/5effective-social-media-marketing-sites-for-restaurants-be8450f2ac22]

American Beverage Licensees Admin, (2018). America's Beer, Wine \& Spirits Retailers Create 2.03 Million Jobs \& \$122.63 Billion in Direct Economic Impact. Retrieved from https://www.ablusa.org/americas-beer-wine-spirits-retailers-create-2-03-million-jobs-122-63billion-in-direct-economic-impact/

Census (2018). The National Census. Retrieved from https://www.census.gov/

Chen, J. (2016). The Complete Guide to Social Media for Restaurants \& Bars. Retrieved from https://sproutsocial.com/insights/bars-restaurants-social-media-guide/

Clement, J. (2019). Global market share of search engines 2010-2019. Retrieved from https://www.statista.com/statistics/216573/worldwide-market-share-of-search-engines/

Cowley, S. (2016). A Liquor License Workaround: Fermented, Not Distilled. Retrieved from https://www.nytimes.com/2016/02/04/business/smallbusiness/restaurants-work-around-liquorlaws-with-wine-based-drinks.html

Datanyze (2019). Datanyze Yelp report. Retrieved from https://www.datanyze.com/marketshare/orm/yelp-market-share

Delzio, S. (2015). 12 Social Media Marketing Tools for Small Business. Social Media Marketing report retrieved from https://www.socialmediaexaminer.com/social-media-marketing-trends-for-smallbusiness/

Florida Legislature (2019). The 2019 Florida Statues - Beverage Law. Official Internet Site of the Florida Legislature. Retrieved from http://www.leg.state.fl.us/Statutes/index.cfm?App mode=Display_Statute\&URL $=0500$ $\underline{0599 / 0562 / 0562 . h t m l}$

Jones, J.M. (2013). U.S. Drinkers Divide between Beer and Wine as a Favorite. Retrieved from https://news.gallup.com/poll/163787/drinkers-divide-beer-wine-favorite.aspx, April $2^{\text {nd }} 2020$.

Gallup Poll (2018). National Beer Wholesalers Association Report-2018. Consumer Preferences in Beer, Wine and Spirits. Retrieved from https://www.nbwa.org/resources/industry-fast-facts

Haughwout S. and Slater, M. (2018). Surveillance Report \#110: Apparent Per Capita Alcohol Consumption, 1977-2016. National Institute on Alcohol Abuse and Alcoholism. Retrieved from https://pubs.niaaa.nih.gov/publications/surveillance110/CONS16.htm

MHG Report (2020). Social Media Influence on Trial and Loyalty. Retrieved from https://mma.prnewswire.com/media/873367/Restaurant Survey.pdf?p=pdf

Moorman, C. and Finch, TA (2017). Marketing Budgets vary by Industry. Retrieved from https://deloitte.wsj.com/cmo/2017/01/24/who-has-the-biggest-marketing-budgets/. 
Pelletier, T. (2018). Global Alcohol Consumption Up In 2017, But U.S. 2018 Wine Exports Uncertain. Retrieved from https://www.forbes.com/sites/thomaspellechia/2018/06/11/global-alcoholconsumption-up-in-2017-u-s-2018-wine-exports-uncertain/\#10d23727314a

Pew Research Center (2019). Retrieved from https://www.pewresearch.org/

Premium Blend Products (2019). Retrieved from https://premiumblend.com/liquor-substitutes

Rashid, A. (2017). Small and medium enterprise development using social media marketing: A research study. iJARS International Journal of Management and Corporate Affairs. 3. https://doi.org/10.20908/ijarsijmca.v3i1.7478. (Retrieved from https://www.researchgate.net/publication/314462877_Small_and_Medium_Enterprise_Developm ent_using_Social_Media_Marketing_A_Research_Study)

Ritchie, H., Roser, M. (2019). Alcohol Consumption. Retrieved from https://ourworldindata.org/alcoholconsumption\#spirits

Smith, S. (2018). ReportBuyer report. Retrieved from https://www.prnewswire.com/news-releases/theglobal-alcoholic-beverages-market-is-accounted-for-1324-1-billion-in-2017-and-is-expected-toreach-1864-2-billion-by-2026-growing-at-a-cagr-of-3-9-during-the-forecast-period$\underline{300683131 . h t m l}$

Times Total Media (2020)._Retrieved from https://marketing-advertising.tampabay.com/timesadvertising-rates/. 

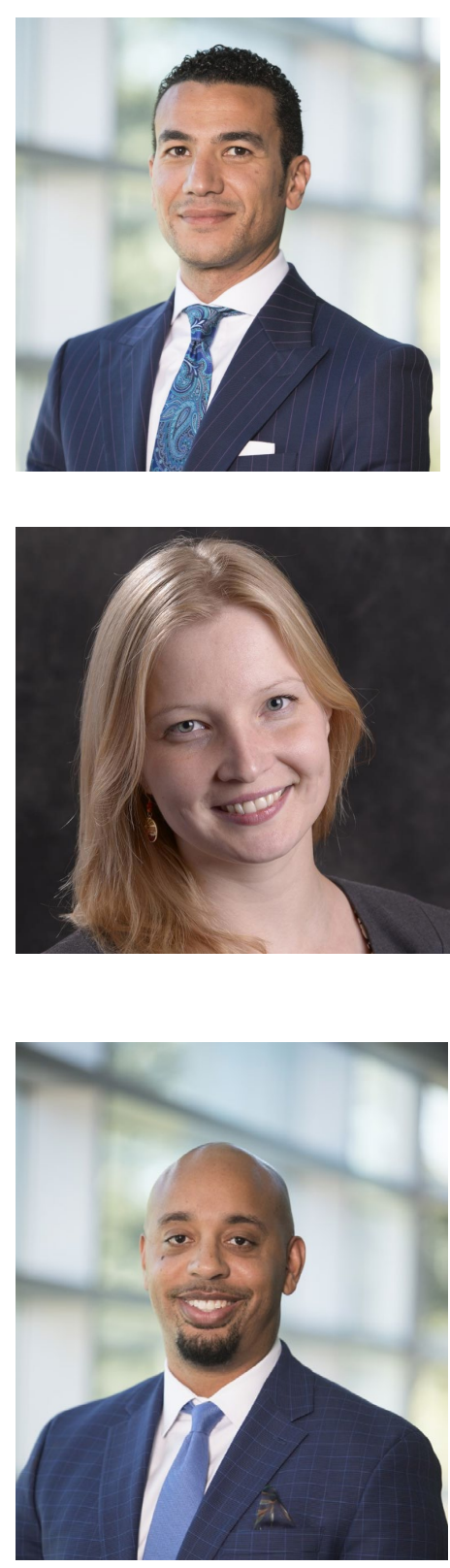

\section{Biographies}

Yamen Elsaid is a Certified Financial Planner ${ }^{\mathrm{TM}}(\mathrm{CFP} \AA)$, the recognized standard of excellence for financial planning. He is also a First Vice President, Portfolio Manager, Financial Advisor and the founder of The Luxor Wealth Management Group at Morgan Stanley, a highly-skilled advisory team located in Sarasota, Florida. Elsaid holds an Executive M.B.A. from the University of South Florida. With more than a decade of investment and banking experience, Yamen combines his analytical skills with an educational approach to guide clients toward the achievement of their specific financial goals. He is committed to delivering exceptional service as he counsels his clients in the areas of retirement planning, investment management, estate planning and lending solutions.

Sarah Hanson is a Field Medical Director at Pfizer, responsible for the pharmaceutical giant's oncology portfolio and working with payers and other managed care organizations. Hanson holds an MD from Radboud University in the Netherlands, a PhD in melanoma research from the University of Groningen, also in the Netherlands, and an Executive M.B.A. from the University of South Florida's Muma College of Business. She uses her extensive background in medicine and research to make oncology treatment broadly accessible. Hanson is passionate about improving cancer care and has won several annual awards at Pfizer for her efforts.

Christopher Lawson earned his B.S in Business Administration from the University of Illinois and an Executive M.B.A. from the University of South Florida's Muma College of Business. After college he worked for Merrill Lynch as a Retirement Specialist where he focused on strategizing and assisting clients with company sponsored retirement plans. After years of traveling and consulting, Lawson and his family decided to start a Marketing Communications company in Tampa, FL. With a passion for helping businesses solve complex marketing problems, Lawson and his team have assisted local and national organizations with expanding the brand presence using digital and traditional marketing efforts. His company has won numerous awards for their outstanding performance has won Business of the Year from local chambers and national diversity organizations. 


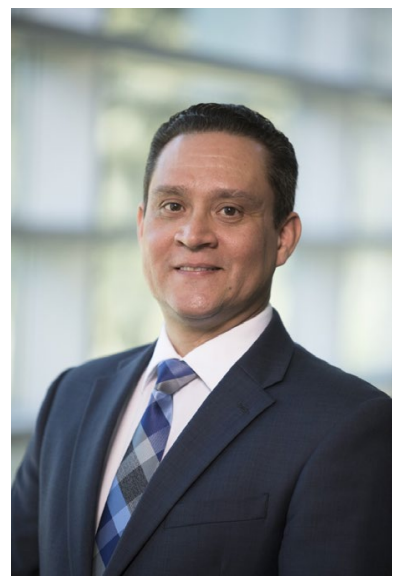

Ivan Montero is the owner of Montero Music, LLC., a music production company based in Tampa, Florida. He holds an Executive M.B.A. from the University of South Florida, where he also received his bachelor's degree in International Studies. He consults with music entrepreneurs including singers, songwriters, and bands to help them publish their work, register songs, and connect with the company's record label, on which he also is a recording artist. $\mathrm{He}$ also works as a professional DJ and performs with a 12-piece salsa band. His primary duties as owner of the business include oversight and registration of intellectual property, tour operations, bookings, promotions, and appearances. Montero also formulates strategic marketing plans, social media presence, merchandise sales, and music releases. He is retired from the U.S. Air Force after 22 years of service.

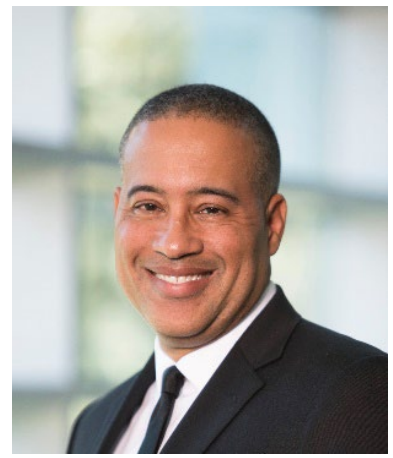

Colin M. Provine earned his B.S. Electrical Engineering from Yale University and his Executive M.B.A. from University of South Florida's Muma College of Business. He is a Senior Director in Procurement at Centene Corporation, a multi-national healthcare enterprise focused on government sponsored managed care services and is responsible for the Procurement Center of Excellence. Colin's 25+ year careers spans global strategic procurement leadership and management roles at Centene, WellCare Health Plans, Honeywell International and Procter \& Gamble. He has a proven ability in optimizing a diverse, world-class supply base to impact measurable business results and competitive advantage. 


\section{Exhibit 1: US Retail Outlets Selling Alcohol}

\section{Total U.S. Retail Establishments Selling Alcohol 2008 to 2018}

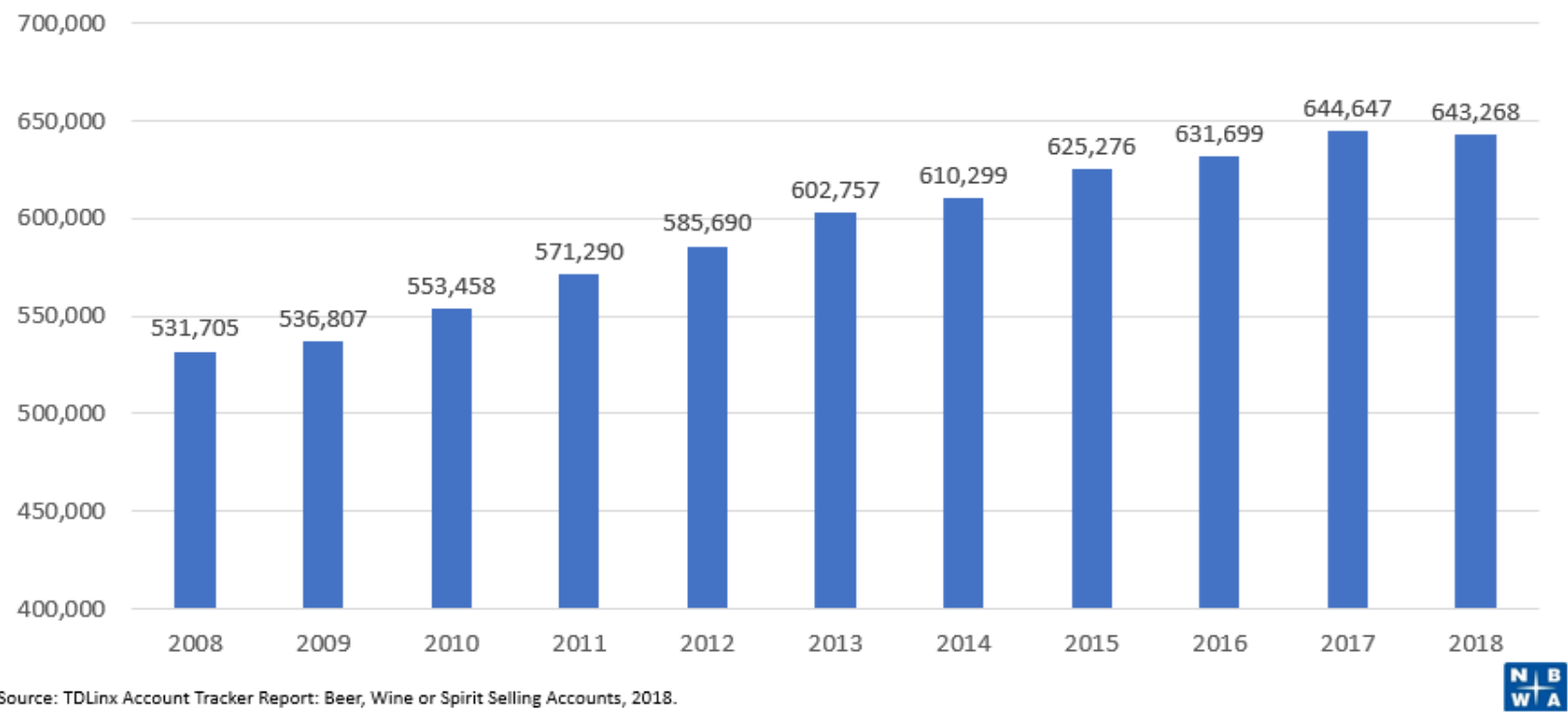

Source: https://www.nbwa.org/resources/industry-fast-facts; TDLinx Account Tracker Report, 2018 


\section{Exhibit 2: USA Alcohol Consumption}

Consumer Preferences in Beer, Wine and Spirits

\section{BEER IS THE PREFERRED BEVERAGE OF CHOICE}

According to the Gallup Poll, 36 percent of people do not consume alcohol. Although there have been articles about widespread shifts of legal drinkers from beer to spirits or wine, the annual Gallup survey has shown remarkable stability in consumer preferences over the past decade.

$\begin{array}{llll}\frac{\text { Year }}{2001} & \underline{\text { Beer }} & \frac{\text { Wine }}{31 \%} & \frac{\text { Spirits }}{18 \%} \\ 2002 & 46 \% & 30 \% & 22 \% \\ 2003 & 44 \% & 33 \% & 22 \% \\ 2004 & 42 \% & 33 \% & 24 \% \\ 2005 & 39 \% & 36 \% & 21 \% \\ 2006 & 49 \% & 33 \% & 23 \% \\ 2007 & 40 \% & 34 \% & 22 \% \\ 2008 & 42 \% & 31 \% & 23 \% \\ 2009 & 40 \% & 34 \% & 21 \% \\ 2010 & 41 \% & 32 \% & 21 \% \\ 2011 & 36 \% & 35 \% & 23 \% \\ 2012 & 39 \% & 35 \% & 22 \% \\ 2013 & 36 \% & 35 \% & 23 \% \\ 2014 & 41 \% & 31 \% & 23 \% \\ 2015 & 42 \% & 34 \% & 21 \% \\ 2016 & 43 \% & 32 \% & 20 \% \\ 2017 & 40 \% & 30 \% & 26 \% \\ 2018 & 42 \% & 34 \% & 28 \%\end{array}$

Source: https://www.nbwa.org/resources/industry-fast-facts; Gallop Poll 2018 


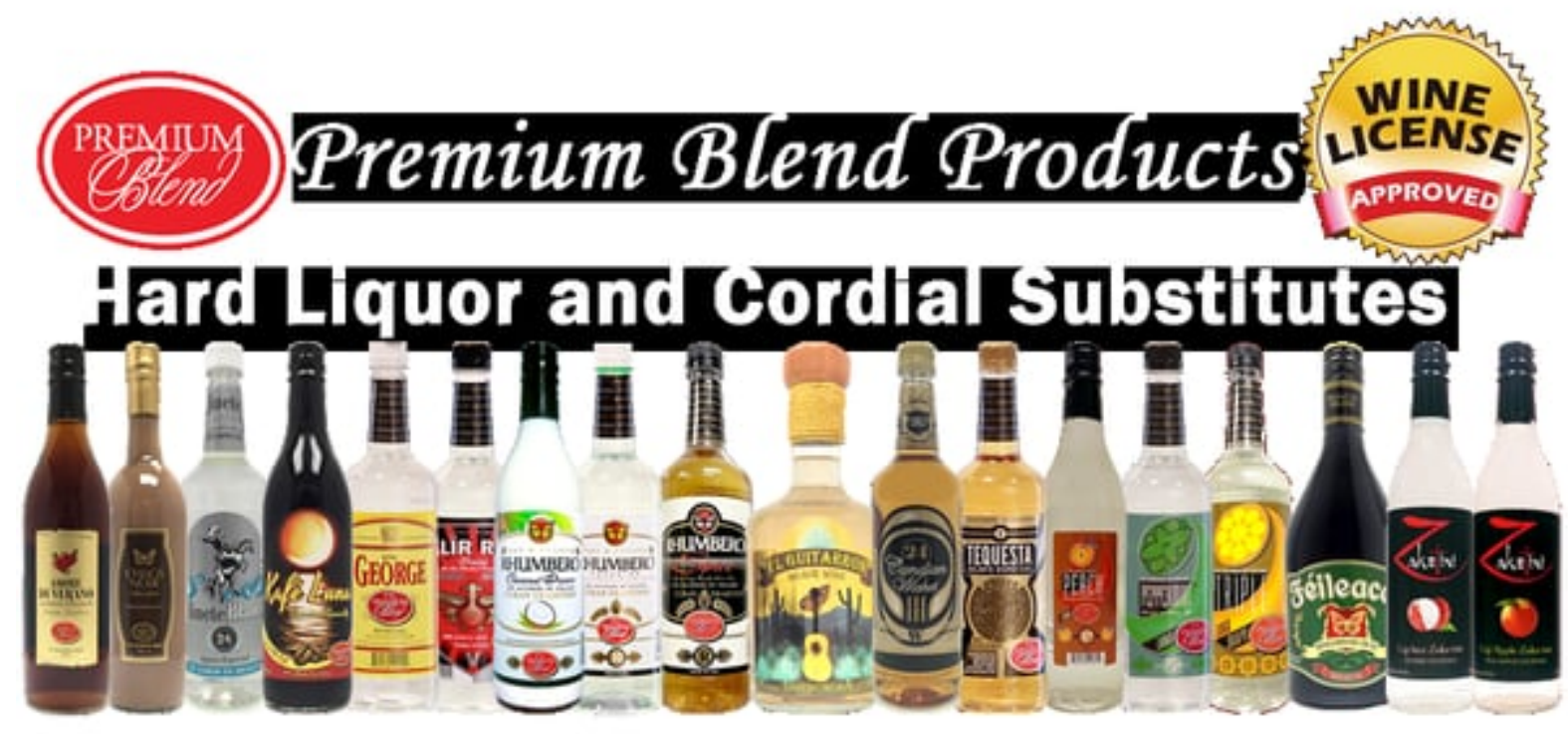

Sell cocktals with your seer and Whe Ircense today

Retrieved from https://premiumblend.com/liquor-substitutes 
Exhibit 4: New Branding at the Hungry Dragon Tavern

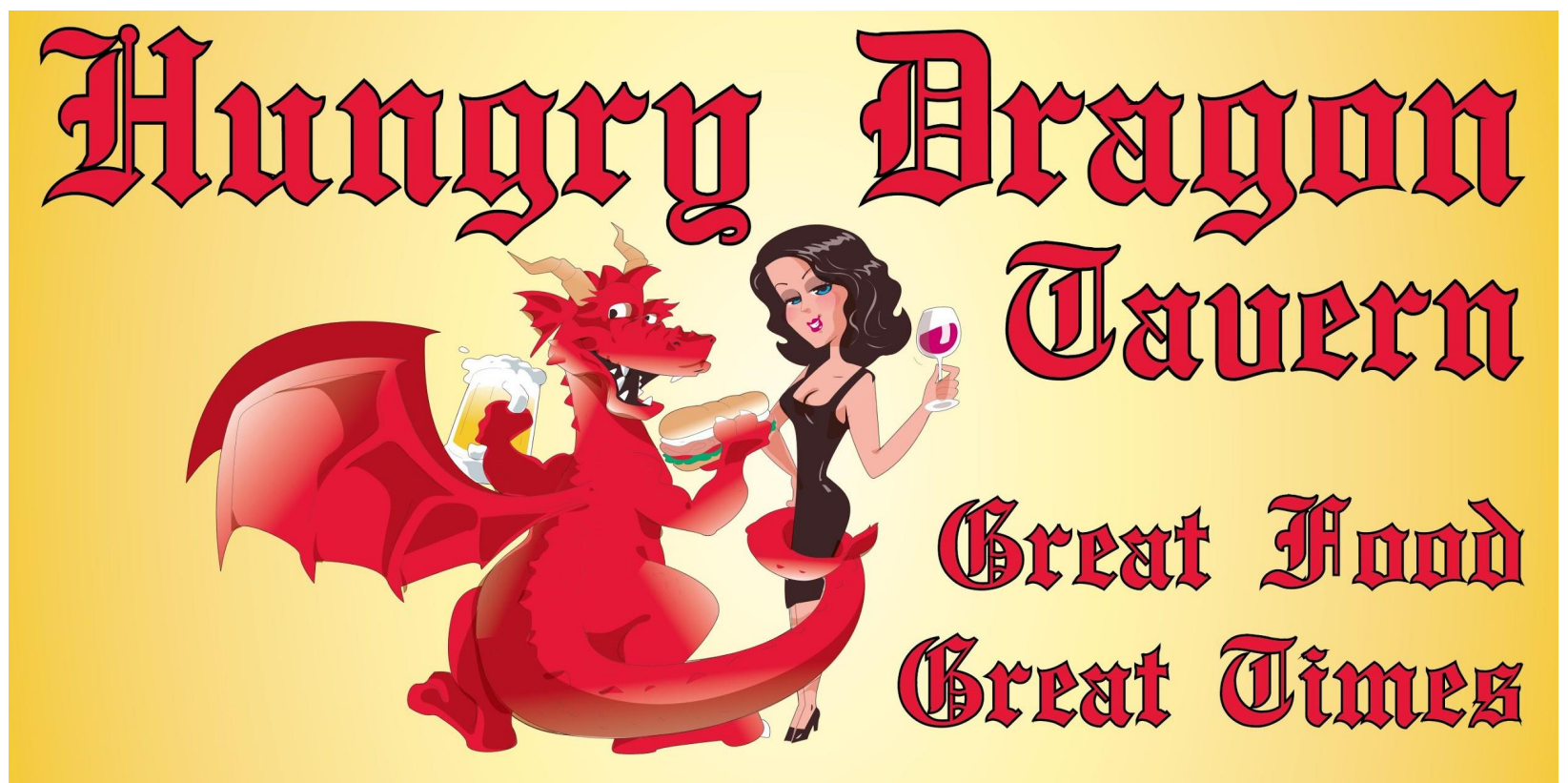

Source: Hungry Dragon Image from Proprietor 


\section{Exhibit 5: Inside the Hungry Dragon Tavern}

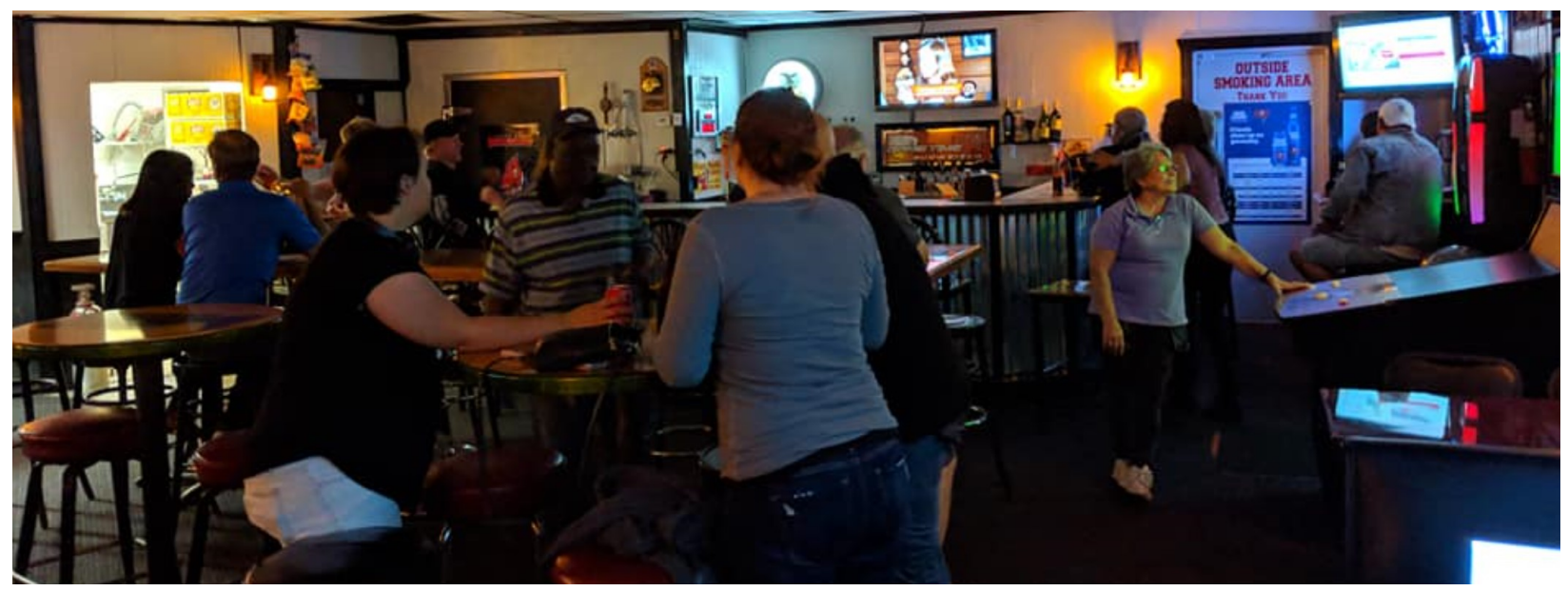

Source: Hungry Dragon Tavern Facebook page 


\section{Exhibit 6: The Hungry Dragon Tavern Menu}

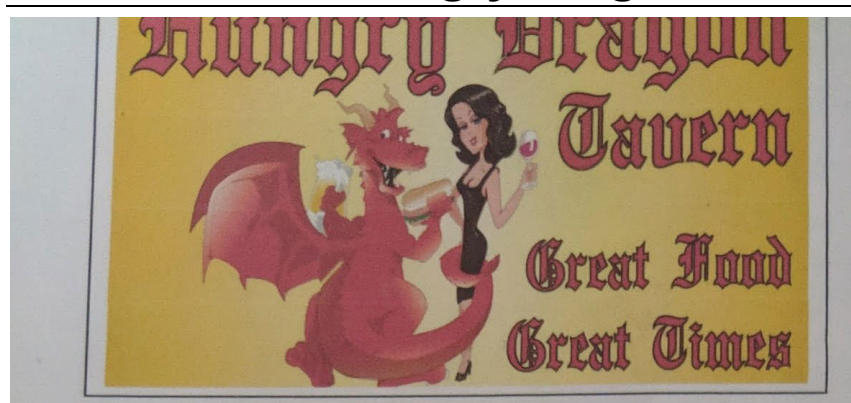

2806 EAST BUSCH BLVD, TAMPA, FL 3301

HOURS: SUNDAY - THURSDAY 12PM - 12 A

FRIDAY \& SATURDAY $12 \mathrm{PM}-2 \mathrm{AM}$

KITCHEN HOURS: $12 \mathrm{PM}-1$ OPM

LAST CALL FOR PICKUP OR DELIVERY 9:30

DELIVERY FEE $\$ 3.00$

SEE OUR DELIVERY AND TAKE OUT SPECIAL

AT HUNGRYDRAGONTAVERN.COM

\section{EATS}

GARLIC BREAD BITES

$\$ 1.95$

TATER TOTS

$\$ 2.95$

CHICKEN TENDERS

$\$ 5.95$

UGLY WINGS

$\$ 6.95$

CHEEse Quesadilla

$\$ 3.95$

PREMIUM HOT DOG

$\$ 2.95$

CHICKEN QUESADILLA

$\$ 4.95$

CHILI/CHEESE DOG

$\$ 3.95$

VEGGIE QUESADILLA

$\$ 4.95$

DRAGON DOG

$\$ 3.95$

DRAGON QUESADILLA

$\$ 5.95$

SMOKED SAUSAGE

$\$ 3.95$

Cuban

$\$ 5.95$

ITALIAN SAUSAGE

$\$ 3.95$

CHICKEN SALAD HoAgIE

$\$ 5.95$

FIVE CHEESE MELT

$\$ 5.95$

ITALIAN MELT

$\$ 5.95$

Meatball Hoagie

$\$ 5.95$

HAM AND CheEse MeLT

$\$ 5.95$

GRILled CHICKEN MELT

$\$ 5.95$

ITALIAN BEEF MELT

$\$ 5.95$

DRAGON MELT

$\$ 6.95$

DRAGON STYLE COME WITH SAUSAGE, RED ONIONS, JALAPENOS, CRUSHED RED PEPPER AND DRAGON SAUCE WING STYLES - DRY RUB, BUFFALO, BBQ, DRAGON SAUCE

THE BEST PIZZA IN THE NEIGHBORHOOD

Cheese

$\begin{array}{cc}\text { SMALL 10" } & \text { LARGE 16" } \\ \$ 5.99 & \$ 11.99 \\ \$ 6.99 & \$ 14.99 \\ \$ 6.99 & \$ 14.99 \\ \$ 6.99 & \$ 14.99 \\ \$ 7.99 & \$ 15.99 \\ \$ 7.99 & \$ 15.99 \\ \$ 8.99 & \$ 17.99 \\ \$ 8.99 & \$ 17.99\end{array}$

TRIPLE PEPPERONI

FOUR CHEESE

CHICKEN - GRILLED CHICKEN \& FRESH MUSHROOMS

VEGGIE - ONIONS, GREEN PEPPERS, MUSHROOM, OLIVES

MEAT - PEPPERONI, SAUSAGE, MEATBALLS, BACON

DELUXE - MEAT PIZZA AND VEGGIE PIZZA COMBINED

$\$ 17.99$

TOPPINGS $\$ 1.50$ EACH FOR 16", \$1.00 FOR 10"

Pepperoni, Sausage, Meatbalis, bacon, Onions, Green Peppers, Mushrooms, Black Olives, Jalapenos 


\section{Exhibit 7: Traditional Marketing Channels}

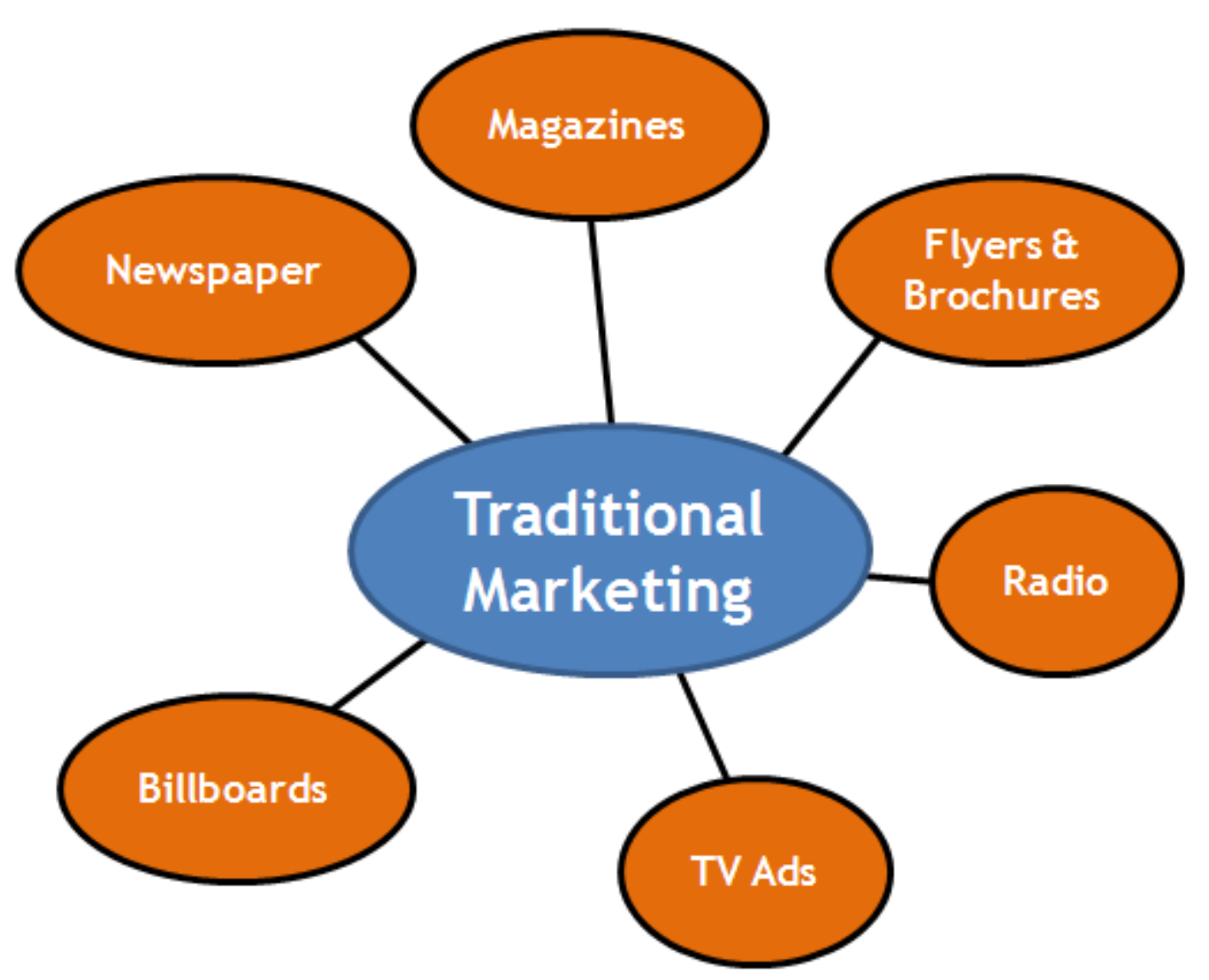

Source: Rashid (2017) 


\section{Exhibit 8: Influence of Social Media on Restaurant Choice}

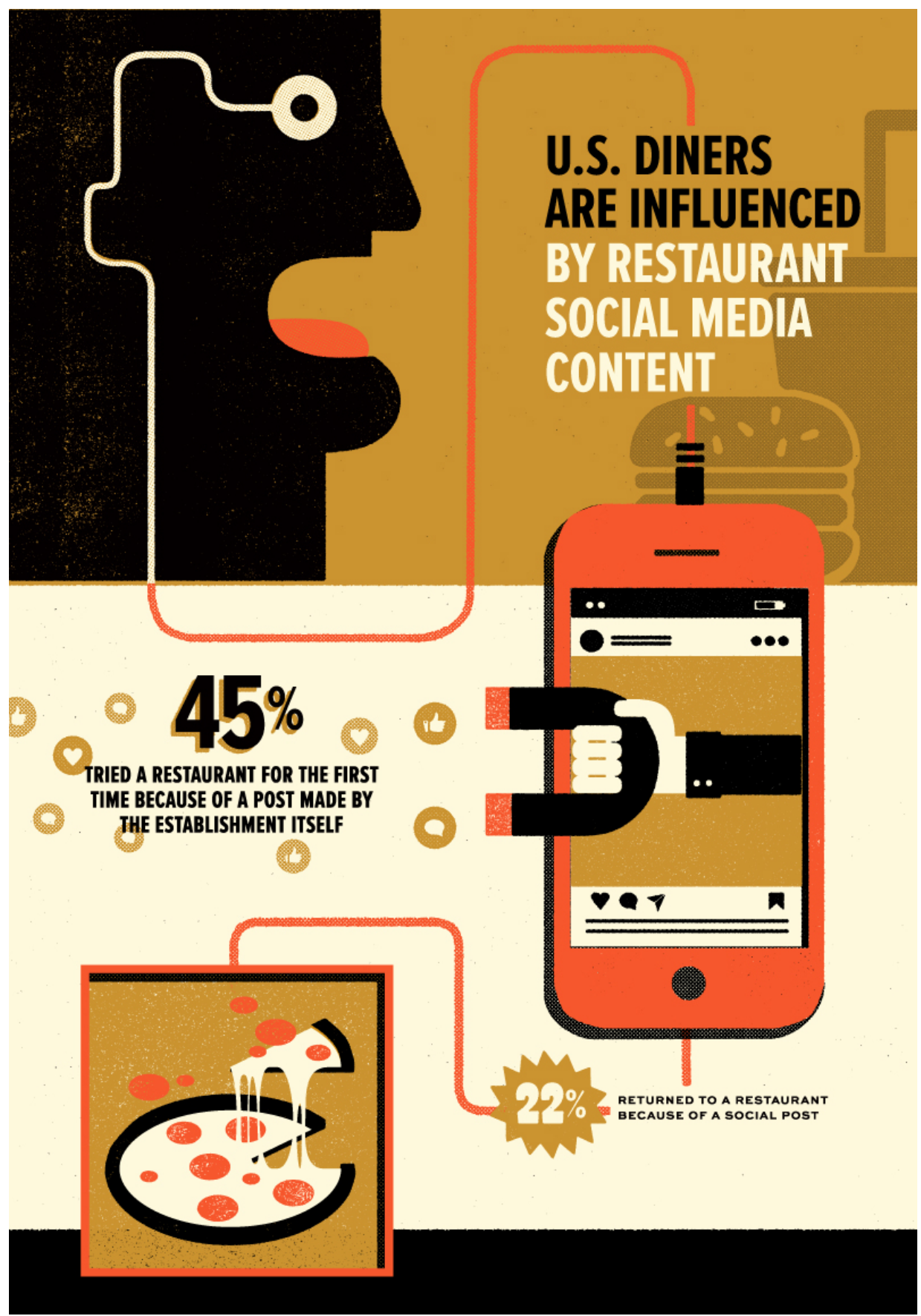

Source: MHG Report, 2020. https://mghus.com/blog/social-media-influences-nearly-half-of-us-diners, 


\section{Exhibit 9: Social Media Channels Used by Small Businesses}

Which Social Media Channels Do Small Businesses Use?

Facebook

Instagram

YouTube

Twitter

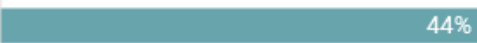

Linkedin

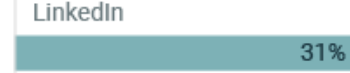

Snapchat

Source: https://clutch.co/agencies/social-media-marketing/resources/small-business-social-media-survey$\underline{2018}$ 


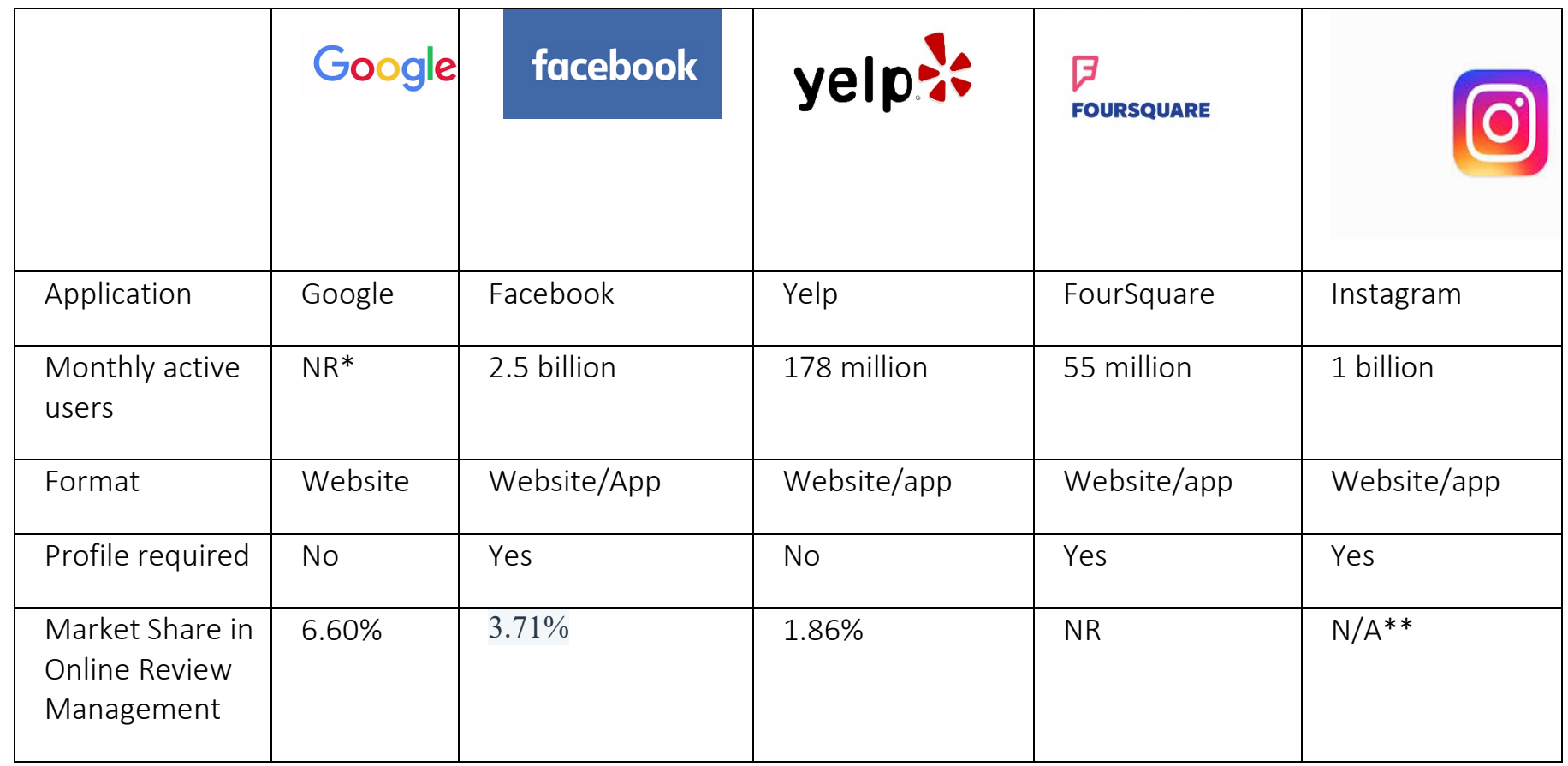

Sources: Datanyze (2019). *Google does not provide statistics on individual active monthly users. **Not a review website 


\section{THDT Digital Marketing Budget Calculator}

\begin{tabular}{|l|c|}
\hline Annual Revenue: & $\$ 96,000$ \\
\hline Your Business Type: & B2C Service \\
\hline $\begin{array}{l}\text { Percent of Annual Revenue Generated } \\
\text { Online: }\end{array}$ & 0 \\
\hline $\begin{array}{l}\text { How Many Internal Staff Are On Your } \\
\text { Marketing Team? }\end{array}$ & 0 \\
\hline View Budget Data As: & Monthly \\
\hline
\end{tabular}

\begin{tabular}{|r|c|c|}
\hline SUMMARY & LOW Monthly & HIGH Monthly \\
\hline Total Marketing Budget & $\$ 1,123$ & $\$ 1,560$ \\
\hline Digital Marketing Budget & $\$ 354$ & $\$ 814$ \\
\hline
\end{tabular}

\begin{tabular}{|r|c|c|}
\hline DETAIL & LOW Monthly & HIGH Monthly \\
\hline Search Advertising & $\$ 64$ & $\$ 147$ \\
\hline Display Advertising & $\$ 35$ & $\$ 81$ \\
\hline Social Advertising & $\$ 42$ & $\$ 98$ \\
\hline Online Advertising Total & $\$ 142$ & $\$ 326$ \\
\hline Email & $\$ 18$ & $\$ 41$ \\
\hline SEO / Content & $\$ 64$ & $\$ 147$ \\
\hline Management, Consulting, Training & $\$ 88$ & $\$ 204$ \\
\hline Marketing Technology & $\$ 42$ & $\$ 98$ \\
\hline Total Digital Marketing Budget & $\$ 354$ & $\$ 814$ \\
\hline
\end{tabular}

